\title{
Block share ownership and corporate earning: Evidence from Tehran Stock Exchange
}

\author{
Somayye Adhami ${ }^{\mathrm{a}^{*}}$ and Mohamad Reza Asgari ${ }^{\mathrm{b}}$
}

\begin{abstract}
${ }^{a}$ M.Sc. Student, Department of Accounting, School of Economic and Accounting, Central Tehran Branch, Islamic Azad University (IAU), Tehran, Iran ${ }^{b}$ Professor and Faculty member, Department of Accounting, School of Economic and Accounting, Central Tehran Branch, Islamic Azad University (IAU), Tehran, Iran

\section{H R O N I C L E}

Article history:

Received April 23, 2012

Received in revised format

22 October 2012

Accepted 26 October 2012

Available online

November 12012

\section{Keywords:}

Tobin's Q

ROA

Block holding

Tehran Stock Exchange

A B S T R A C T

During the past few years, there have been growing interests among researchers to study the effect of block share ownership on corporate earning especially in developing countries. The purpose of this paper is to consider the impact of block ownership on performance of firms in terms of profitability. The proposed study develops two econometric models and applies them on selected firms from Tehran Stock Exchange over the period 2002-2010. The primary objective of this survey is to find the relationship between return of assets and Tobin's Q as dependent variables with eight independent variables including company size, sales growth, block ownership, debt and liability ratios, etc. The results of implementation of ordinary least squares on two econometric models reveal that while there is no meaningful relationship between return of asset and block ownership there is a meaningful relationship between block ownership and Tobin's Q.
\end{abstract}

C) 2013 Growing Science Ltd. All rights reserved.

\section{Introduction}

During the past few years, there have been growing interests among researchers to study the effect of block share ownership on corporate earning especially in developing countries. King and Santor (2008) examined how family ownership impacts the performance and capital structure of 613 Canadian firms over the period 1998- 2005. They distinguished the impact of family ownership from the use of control-enhancing mechanisms and reported that freestanding family owned firms with a single share class had similar market performance than other firms based on Tobin's q ratios, superior accounting performance based on ROA, and higher financial leverage based on debt-to-total assets. However, family owned firms, which implement dual-class shares had valuations, which were lower by $17 \%$ on average compared with widely held firms, despite having similar ROA and financial leverage. Andres (2008) examined the relationship between founding-family ownership and firm performance by applying panel information on 275 German exchange-listed firms. He showed that family firms were not only more profitable than widely-held firms but also outperform firms with

*Corresponding author. Tel: +98-912-3443139

E-mail addresses: s.adhami@yahoo.com (S. Adhami) 
other kinds of blockholders by separating the family impact from general blockholder impacts. Nevertheless, the performance of family businesses was only better in firms where the foundingfamily was still active either on the executive or on the supervisory board. They recommended that family ownership was associated with superior firm performance only under certain circumstances. If families were just large shareholders without board representation, the performance of their companies would not distinguishable from other firms. The results also indicated that other blockholders either influenced firm performance adversely or had no detectable influence on performance measures.

Kim and Lu (2011) investigated the relationship between CEO ownership and firm valuation hinges critically on the strength of external governance (EG). The relationship was hump-shaped when EG was weak, but was insignificant when EG was strong. The results implied that CEO ownership and EG were substitutes for mitigating agency problems when ownership was low. However, very high levels of share ownership could reduce firm value by entrenching the CEO and discouraging him from taking risk, unless mitigated by strong EG. They identified channels through which CEO ownership affected firm value by examining $R \& D$, which was discretionary and risky. They found CEO ownership similarly exhibited a hump-shaped relationship with R\&D when EG was weak, but no relationship when EG was strong.

Jeon et al. (2011) studied the relationship between foreign ownership and the decisions on payout policy in the Korean stock market. They reported that foreign investors demonstrate a preference for firms that pay high dividends. The results were driven by the fact that most of the foreign investors in the Korean market were institutional investors and thus had both dividend clienteles and monitoring incentives. However, foreign investors neither expressed preference for firms that buy back shares, nor were they related to encouraging firms to increase repurchases. They reported little evidence that domestic institutions had a significant impact on payout policy.

Chen et al. (2012) investigated the effect of insider managerial ownership on financial performance of publicly traded tourist hotels in Taiwan. Insider managerial shareholding (IMS) incorporated two various classes of owners including managers and directors. The indicators of financial performance under consideration were return on assets (ROA), return on equity (ROE), stock return (SR), and Tobin's Q. In addition to analyze total insider managerial ownership (IMS), the study splited IMS into two components (MAS and DIRS) and examined each of them, separately. Subsequently, panel regression tests investigated the impacts of IMS, MAS, and DIRS on financial performance of Taiwanese tourist hotels. Test results recommended that IMS explained ROA, ROE and Tobin's Q, but not SR. Further, compared to MAS, DIRS had a more significant effect on hotel performance. Bennedsen and Meisner Nielsen (2010) reported that there was a higher value discount in family firms, in firms with low cash flow concentration, and in industries with higher amenity value.

Barry et al. (2011) analyzed the link between ownership structure and risk in both privately owned and publicly held banks. They considered five categories of shareholders, which were specific to their dataset and reported that ownership structure was significant in explaining risk differences but mainly for privately owned banks. Lin et al. (2009) provided some new insights to the debate regarding the merits of bank equity ownership of companies and emphasized how banking and corporate finance behaved differently in emerging markets due to their unique institutional background.

\section{The proposed study}

The proposed study of this paper uses the historical information of stocks traded on Tehran Stock Exchange over the period 2002-2010. In our survey, we consider four major criteria for picking the stocks, which are as follows,

1. Firm must be tradable before year 2002 and it must have been actively traded during the years of study. 
2. Firm should not have changed their fiscal year during the period of study.

3. No holding or investment companies are permitted in this survey.

4. All necessary information must be available.

Based on these criteria, we could determine 142 firms for the proposed study of this research and using 1278 year-firm from 24 different industries, the proposed study of this paper considers the following two hypotheses,

1. There is a meaningful relationship between return of assets and block ownership status.

2. There is a meaningful relationship between Tobin's $Q$ and block ownership.

\subsection{Dependent variable}

\subsubsection{Return of assets}

Return of assets (ROA) is the first variable of this work and it is computed as follows,

$$
R O A_{i, t}=\frac{E B T_{i, t}}{\text { Asset }_{i, t}},
$$

where $E B T_{i, t}$ is the earning before tax and Asset $_{\mathrm{i}, \mathrm{t}}$ is total book value of all assets associated with firm $i$ at time $t$.

\subsubsection{QTobin}

This ratio measures the performance of firms based on Q Tobin,

$$
\mathrm{QTobin}_{i, t}=\frac{S_{-} M V_{i, t}+S T D_{-} B V_{i, t}+L T D_{-} B V_{i, t}}{T A_{-} B V_{i, t}},
$$

where $S \_M V i, t$ is market value of firm $i$ at time $t, S T D \_B V_{i, t}$ is the book value of short term debts of firm $i$ at time $t, L T D \_B V_{i, t}$ is the book value of long term liabilities of firm $i$ at time $t$ and finally TA_BVi,t is total asset book value of firm $i$ at time $t$.

\subsection{Independent variables}

\subsubsection{Block owners $\left(L B O W N_{i, t}\right)$}

This variable represents the ownership of small number of shareholders who own big portions of shares. The primary objective of these shareholders is to have, at least, one member in board of directors and in Tehran Stock Exchange, this ratio is calculated as follows,

$$
B S=\frac{N}{B+1}+1
$$

where $N$ is total number of outstanding shares, $B$ is total number of members of board of directors and $B S$ determines the number of seats.

\subsection{Control variables}

\subsubsection{The number of board of directors $\left(B D S I Z E_{i, t}\right)$}

This variable determines the number of seats in board of directors in a firm.

\subsubsection{Debt ratio $\left(D R_{i, t}\right)$}

This is the ratio of total liabilities (TotalDebit) on total assets (TotalAsset) and shows what portion of financing is provided through borrowing money from banks or other financial institutions. 
$D R_{i, t}=\frac{\text { TotalDebit }_{i, t}}{\text { TotalAsset }_{i, t}}$.

2.3.3. Liquidity ratio $\left(L I Q_{i, t}\right)$

This is the ratio of total current assets (Cuttent_Assets) on total current liabilities (Current_Liabilities) as follows,

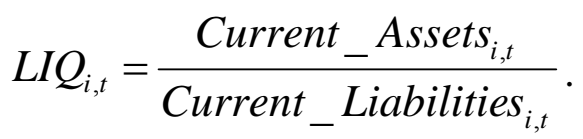

2.3.4 Age $\left(A G E_{i, t}\right)$

This ratio is calculated by taking the natural logarithm of a firm from the year it started its business activities.

\subsubsection{Size $\left(\operatorname{SIZE}_{i, t}\right)$}

This variable is computed by taking natural logarithm of market cap.

2.3.6. Growth $\left(G R O W T H_{i, t}\right)$

This ratio shows the relative growth of firm's sale $i$ at time $t$ and it is calculated as follows,

GROWTH $_{i, t}=\frac{\text { Sale }_{i, t}-\text { Sale }_{i, t-1}}{\text { Sale }_{i, t-1}}$.

\subsubsection{Risk $\left(\right.$ RISK $\left._{i, t}\right)$}

Risk of a firm $\left(R I S K_{i, t}\right)$ is calculated as the standard deviation of the monthly return of firms during the fiscal year.

\subsection{Data gathering}

The proposed study of this paper gathers the necessary information from Tehran Stock Exchange and the regression analysis have been performed using Eviews and SPSS software packages.

2.5. The proposed models

The proposed study of this paper uses two econometrics models as follows,

$$
\begin{aligned}
\operatorname{ROA}_{i, t}= & \alpha+\beta_{1} \mathrm{LBOWN}_{i, t}+\beta_{2} \mathrm{BDSIZE}_{i, t}+\beta_{3} D R_{i, t}+\beta_{4} L I Q_{i, t}+\beta_{5} A G E_{i, t} \\
& +\beta_{6} \operatorname{SIZE}_{i, t}+\beta_{7} \operatorname{GROWTH}_{i, t}+\beta_{8} \operatorname{RISK}_{i, t}+\varepsilon_{i t} \\
\text { QTobin }_{i, t}= & \alpha+\beta_{1} L B O W N_{i, t}+\beta_{2} \text { BDSIZE }_{i, t}+\beta_{3} D R_{i, t}+\beta_{4} L I Q_{i, t}+\beta_{5} A G E_{i, t} \\
& +\beta_{6} \operatorname{SIZE}_{i, t}+\beta_{7} \mathrm{GROWTH}_{i, t}+\beta_{8} \operatorname{RISK}_{i, t}+\varepsilon_{i t}
\end{aligned}
$$

\section{The results}

Table 1 shows details of statistical observations for the proposed study of this paper. 
Table 1

Statistical observations

\begin{tabular}{llllllll}
\hline Variable & $\begin{array}{l}\text { Number of } \\
\text { observations }\end{array}$ & Mean & $\begin{array}{l}\text { Standard } \\
\text { deviation }\end{array}$ & $\begin{array}{l}\text { Lowest } \\
\text { value }\end{array}$ & $\begin{array}{l}\text { Highest } \\
\text { value }\end{array}$ & Skewness \\
\hline ROA & 1277 & 0.1536 & 0.1565 & -0.3097 & 0.8111 & 1.009 & 4.739 \\
QTOBIN & 1277 & 1.6024 & 1.1788 & 0.2333 & 11.8044 & 4.163 & 25.149 \\
LBOWN & 1277 & 56.272 & 24.981 & 0.0000 & 99.513 & 0.637 & 2.996 \\
BDSIZE & 1277 & 5.068 & 0.3395 & 3 & 7 & 4.017 & 23.982 \\
DR & 1277 & 0.6735 & 0.1758 & 0.0000 & 1.9011 & 0.429 & 6.514 \\
LIQ & 1277 & 1.1888 & 0.5257 & 0.0000 & 6.4713 & 3.131 & 23.420 \\
AGE & 1277 & 3.5058 & 0.3507 & 1.3862 & 4.0604 & -1.211 & 5.196 \\
SIZE & 1277 & 12.4708 & 1.5300 & 8.4319 & 17.2060 & 0.693 & 3.038 \\
GROWTH & 1277 & 0.2016 & 0.5264 & -1.0000 & 9.4684 & 9.014 & 130.657 \\
RISK & 1277 & 2.3458 & 1.0081 & -4.2381 & 5.6879 & -1.072 & 6.778 \\
\hline
\end{tabular}

Table 2 shows details of the implementation of ordinary least square for Eq. (7)

Table 2

The results of regression model

\begin{tabular}{|c|c|c|c|c|c|}
\hline & & Coefficient & t-student & P-value & Result \\
\hline Intercept & $\alpha$ & 0.0961 & 8.180 & 0.0000 & Positive \\
\hline LBOWN & $\beta_{1}$ & -0.0001 & -0.725 & 0.4682 & Not significant \\
\hline BDSIZE & $\beta_{2}$ & 0.0017 & 0.2852 & 0.7755 & Not significant \\
\hline DR & $\beta_{3}$ & -0.2155 & -9.358 & 0.0000 & Negative \\
\hline LIO & $\beta_{4}$ & 0.0334 & 4.972 & 0.0000 & Positive \\
\hline AGE & $\beta_{5}$ & -0.3548 & -12.620 & 0.0000 & Negative \\
\hline SIZE & $\beta_{6}$ & 0.0424 & 11.833 & 0.0000 & Positive \\
\hline GROWTH & $\beta_{7}$ & 0.0343 & 9.649 & 0.0000 & Positive \\
\hline RISK & $\beta_{8}$ & -0.0011 & -0.7593 & 0.4478 & Not significance \\
\hline $\operatorname{AR}(1)$ & & 0.3961 & 14.200 & 0.0000 & Positive \\
\hline
\end{tabular}

In addition, Table 3 shows details of implementation of various statistical tests on the first model.

Table 3

Statistical tests for the first model

\begin{tabular}{lcclcll}
\hline & Ramsey & Durbin-Watson & & \multicolumn{2}{c}{ Breusch-Pagan } & \multicolumn{2}{c}{ Jarque-Bera } \\
\hline F & P-value & D & F & P-value & Chi-Square & P-value \\
0.2098 & 0.6469 & 1.98 & 5.407 & 0.0000 & 1.033 & 0.5963 \\
\hline
\end{tabular}

As we can observe from the results of Table 3, Durbin=Watson ratio is calculated as 1.98 , which means there is no correlation between residuals. Based on the results of Table 2, we can conclude that there is not any meaningful relationship between return of assets and block ownership and the first hypothesis of this paper is rejected when the level of significance is five percent. Table 4 shows details of the implementation of ordinary least square for Eq. (8).

\section{Table 4}

The results of regression model

\begin{tabular}{llllll}
\hline & & Coefficient & t-student & P-value & Result \\
\hline Intercept & $\alpha$ & -6.6164 & -5.830 & 0.0000 & Negative \\
LBOWN & $\beta_{1}$ & 0.0015 & 2.348 & 0.0190 & Positive \\
BDSIZE & $\beta_{2}$ & 0.0076 & 0.2846 & 0.7760 & Not significant \\
DR & $\beta_{3}$ & 1.1767 & 12.691 & 0.0000 & Positive \\
LIO & $\beta_{4}$ & -0.0212 & -0.919 & 0.3580 & Not significant \\
AGE & $\beta_{5}$ & -2.0281 & -6.576 & 0.0000 & Negative \\
SIZE & $\beta_{6}$ & 1.0103 & 68.933 & 0.0000 & Positive \\
GROWTH & $\beta_{7}$ & -0.0195 & -2.082 & 0.0375 & Negative \\
RISK & $\beta_{8}$ & -0.0007 & -0.131 & 0.8954 & Not significance \\
AR(1) & & 0.6915 & 35.691 & 0.0000 & Positive \\
\hline
\end{tabular}


In addition, Table 5 shows details of implementation of various statistical test to verify the first model.

Table 5

Statistical tests for the first model

\begin{tabular}{lllllll}
\hline Ramsey & & Durbin-Watson & \multicolumn{2}{l}{ Breusch-Pagan } & Jarque-Bera & \\
\hline F & P-value & D & F & P-value & Chi-Square & P-value \\
3.527 & 0.0606 & 2.04 & 7.728 & 0.0000 & 2.1524 & 0.3408 \\
\hline
\end{tabular}

As we can observe from the results of Table 6, Durbin=Watson ratio is calculated as 2.04, which means there is no correlation between residuals. Based on the results of Table 4, we can conclude that there is a meaningful relationship between Tobin' Q and block ownership and the first hypothesis of this paper is confirmed when the level of significance is five percent. In other word, an increase of one percent on block ownership will yield 0.0015 unit increase in Tobin's Q.

\section{Conclusion}

In this paper, we have presented an empirical study to find the relationship between return of assets and Tobin's Q as dependent variables with eight independent variables including company size, sales growth, block ownership, debt and liability ratios, etc. The results of implementation of ordinary least squares on two econometric models have disclosed that while there was no meaningful relationship between return of asset and block ownership there was a meaningful and positive relationship between block ownership and Tobin's Q.

\section{References}

Andres, C. (2008). Large shareholders and firm performance-An empirical examination of founding-family ownership. Journal of Corporate Finance, 14(4), 431-445.

Barry, T.A., Lepetit, L., \& Tarazi, A. (2011). Ownership structure and risk in publicly held and privately owned banks. Journal of Banking \& Finance, 35(5), 1327-1340.

Bennedsen, M., \& Meisner Nielsen, K. (2010). Incentive and entrenchment effects in European ownership. Journal of Banking \& Finance, 34(9), 2212-2229

Chen, M.H., Hou, C.L., \& Lee, S. (2012). The impact of insider managerial ownership on corporate performance of Taiwanese tourist hotels. International Journal of Hospitality Management, 31(2), 338-349.

Jeon, J.Q., Lee, C., \& Moffett, C.M. (2011). Effects of foreign ownership on payout policy: Evidence from the Korean market. Journal of Financial Markets, 14(2), 344-375.

Kim, E.H., \& Lu, Y. (2011). CEO ownership, external governance, and risk-taking. Journal of Financial Economics, 102(2), 272-292

King, M.R., \& Santor, E. (2008). Family values: Ownership structure, performance and capital structure of Canadian firms. Journal of Banking \& Finance, 32(11), 2423-2432.

Lin, X., Zhang, Y., \& Zhu, N. (2009). Does bank ownership increase firm value? Evidence from China. Journal of International Money and Finance, 28(4), 720-737. 